\title{
Double-positive T Lymphocytes Do Not Vary in Different Age Groups in Colombian Blood Donors
}

\author{
Kolombiyalı Kan Vericilerinde Çift-pozitif T Lenfositler Değişik Yaş Gruplarında Farkııık \\ Göstermemektedir
}

\author{
(D) Miguel S. Gonzalez-Mancera, (D) John Mario Gonzalez \\ Universidad de los Andes, School of Medicine, Grupo de Ciencias Básicas Médicas, Bogotá, Colombia
}

To the Editor,

We read with interest the letter of Gonzalez-Mancera et al. [1] regarding the percentages and absolute numbers of doublepositive T cells (DPTs) in the peripheral blood of a normal Italian population. In a previous article by our group, the DPT population was evaluated in one hundred suitable donors from a Colombian blood bank using flow cytometry. Our main findings showed a median DPT value of $2.6 \%$ and a higher percentage in women.

In the Italian cohort, they found an increase of DPTs with age and no difference by sex. In our original study, we did not test donors over 61 years old to corroborate if age is associated with the marked increased level of DPTs above this age, as shown in the Italian population. We reanalyzed our data and did not find a difference in the percentages of DPTs when comparing age groups (Figure 1).

In the Spanish and German cohorts, although there was no significant difference in DPTs according to sex, women showed a tendency to have more DPTs when compared to men $[2,3]$.

The flow cytometry panel (monoclonal antibodies and fluorochromes) used in our work detected and discriminated the DPTs through manual gating as shown in the original

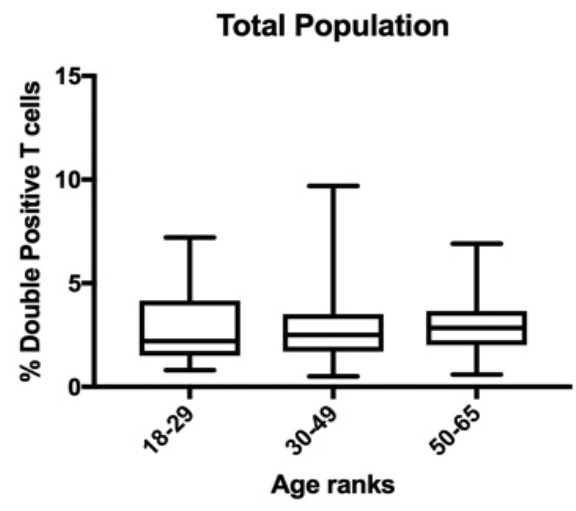

Figure 1. Median and interquartile rankings of donors according to age group. Kruskal-Wallis, $p=0.83$. publication [1]. Previous studies showed that the antibody cocktail and the gating strategy (manual versus automated) are sources of variability in the results [4]. Also, according to our original flow cytometry analysis [1], it was possible to determine the subpopulations of $\mathrm{CD} 4^{\text {high }} \mathrm{CD} 8^{\text {low }}$ and $\mathrm{CD} 4^{\text {low }} \mathrm{CD} 8^{\text {high }}$ in healthy donors as described by other authors $[5,6]$.

In order to understand the differences found in these publications, future studies must include a more diverse population, larger samples, and increased age range.

Keywords: T lymphocytes, Flow cytometry

Anahtar Sözcükler: T lenfosit, Akım sitometrisi

Informed Consent: Not relevant.

\section{Authorship Contributions}

Analysis or Interpretation: M.S.G., J.M.G.; Literature Search: M.S.G., J.M.G.; Writing: M.S.G., J.M.G.

Conflict of Interest: The authors declare no conflict of interest.

Financial Disclosure: The authors declared that this study received no financial support.

\section{References}

1. Gonzalez-Mancera MS, Bolaños NI, Salamanca M, Orjuela GA, Rodriguez AN, Gonzalez JM. Percentages of CD4+CD8+ double-positive T Iymphocytes in the peripheral blood of adults from a blood bank in Bogotá, Colombia. Turk J Hematol 2019;37:36-41.

2. Garcia-Dabrio MC, Pujol-Moix N, Martinez-Perez A, Fontcuberta J, Souto JC, Soria JM, Nomdedéu JF. Influence of age, gender and lifestyle in lymphocyte subsets: report from the Spanish Gait-2 Study. Acta Haematol 2012;127:244-249.

3. Melzer S, Zachariae S, Bocsi J, Engel C, Löffler M, Tárnok A. Reference intervals for leukocyte subsets in adults: results from a population-based study using 10-color flow cytometry. Cytometry B Clin Cytom 2015;88:270-281.

4. Maecker HT, Rinfret A, D'Souza P, Darden J, Roig E, Landry C, Hayes P, Birungi J, Anzala O, Garcia M, Harari A, Frank I, Baydo R, Baker M, Holbrook 
J, Ottinger J, Lamoreaux L, Epling CL, Sinclair E, Suni MA, Punt K, Calarota S, El-Bahi S, Alter G, Maila H, Kuta E, Cox J, Gray C, Altfeld M, Nougarede N, Boyer J, Tussey L, Tobery T, Bredt B, Roederer M, Koup R, Maino VC, Weinhold K, Pantaleo G, Gilmour J, Horton H, Sekaly RP. Standardization of cytokine flow cytometry assays. BMC Immunol 2005;6:13.
5. Nascimbeni M, Shin EC, Chiriboga L, Kleiner DE, Rehermann B. Peripheral CD4+ CD8+ T cells are differentiated effector memory cells with antiviral functions. Blood 2004;104:478-486.

6. Sullivan $Y B$, Landay $A L$, Zack JA, Kitchen SG, Al-Harthi L. Upregulation of CD4 on $C D 8^{+} T$ cells: $C D 4^{\text {dim }} C D 8^{\text {bright }} T$ cells constitute an activated phenotype of CD8+ T cells. Immunology 2001;103:270-280.

\title{
A Novel Mutation in a Patient with Wiskott-Aldrich Syndrome
}

\section{Wiskott-Aldrich Sendrom'lu Bir Hastada Yeni Bir Mutasyon}

\author{
(D) Yurday Öncül1, (D) Arzu Akyay¹, (D) ibrahim Tekedereli2 \\ 1 Inönü University Faculty of Medicine, Division of Pediatric Hematology, Malatya, Turkey \\ 2inonu University Faculty of Medicine, Division of Medical Genetics, Malatya, Turkey
}

\section{To the Editor,}

We read with great interest the recently published article in your journal by Kaya et al. [1] regarding a novel mutation in the Wiskott-Aldrich syndrome (WAS) gene. After that publication, we also had a patient with another novel mutation in the WAS gene from Turkey.

A 3-month-old boy was admitted to our hospital with the complaints of cough, wheezing, and eczema. He also had a history of pneumonia. On physical examination, diffuse eczema was observed (Figure 1), along with widespread petechiae and pulmonary crepitant rales and rhonchi. His family history was unremarkable. Laboratory analysis revealed anemia (hemoglobin of $8.9 \mathrm{~g} / \mathrm{dL}$ ), leukocytosis (white blood count of $13,330 / \mathrm{mm}^{3}$ ), and thrombocytopenia (platelet count of $63,000 / \mathrm{mm}^{3}$ ). Mean platelet volume was $4.8 \mathrm{fL}$. A peripheral blood smear revealed thrombocytopenia and micro-thrombocytes. Immunoglobulin levels were normal. Peripheral lymphocyte subset analysis revealed reduced CD3 percentage and CD16/CD56 ratio. With these results, patient was diagnosed with WAS, and molecular genetic analysis revealed a novel mutation in the WAS gene, a hemizygous c.11_12insGG p.G4Afs mutation on exon 1 (Figure 2). The patient is 18 months old now. Human intravenous immunoglobulin therapy was administered monthly, and thrombocyte replacement was done in case of need [2]. He did not have a family donor, so he was scheduled for allogeneic hematopoietic stem cell transplantation from an unrelated donor.

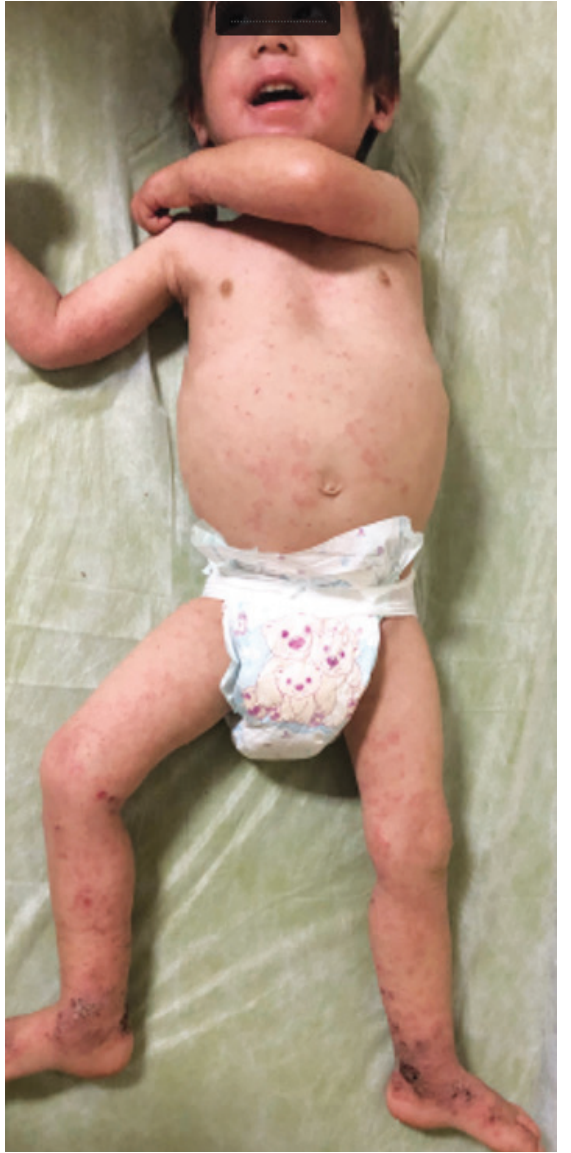

Figure 1. Physical examination revealed diffuse eczema, widespread petechiae, and pulmonary crepitant rales and rhonchi. 